\title{
Teamworking and organizational performance: A review of survey-based research
}

\section{Anne Delarue, ${ }^{1}$ Geert Van Hootegem, Stephen Procter and Mark Burridge}

This paper presents a review of recent survey-based research looking at the contribution of teamwork to organizational performance. In particular, it focuses on empirical studies in which both teamwork and performance are directly measured in a quantitative way. The paper begins by identifying four interrelated dimensions of teamwork effectiveness: attitudinal, behavioural, operational and financial. The first two represent transmission mechanisms by which organizational performance can be improved. The latter two provide direct measures of organizational outcomes. The review shows that teamworking has a positive impact on all four dimensions of performance. It also reveals that, when teamwork is combined with structural change, performance can be further enhanced. The paper concludes by highlighting some important research gaps that future studies could address.

\section{Introduction}

Teamwork has emerged in recent years as one of the most important ways in which work is being reorganized (Osterman 1994; Waterson et al. 1997). This idea of delegating responsibilities to work groups has been diffused under a range of different labels. Human resource management (HRM), modern sociotechnical theory, business process re-engineering and lean production all embrace the core principles of teamworking (Benders and Van Hootegem 1999; De Sitter et al. 1997; Kleinschmidt and Pekruhl 1994; Kuipers and Van Amelsvoort
1990) and suggest an important link with organizational performance (Hammer and Champy 1993; Katzenbach and Smith 1993; Womack et al. 1991).

Various arguments have been advanced to explain the effectiveness of team-based work. For example, both sociotechnical theory (e.g. De Sitter 1994; Pasmore 1988) and work design theory (Hackman and Oldham 1976) have focused on the design of the group's task to explain positive results; self-leadership theory has identified the supervisory behaviours that help self-managing teams achieve success (Manz and Sims 1987); and theories of participative 


\section{Teamworking and organizational performance}

management argue that certain aspects of the organizational context contribute to the effectiveness of teams (e.g. Lawler 1992; Glew et al. 1995).

However, theoretical arguments about the effectiveness of teams are not enough. The next logical step in the cycle of scientific enquiry is the testing of these theories in practice. Various methodological approaches can be taken to assess the benefits associated with teams. Field experiments or intensive case studies allow the careful monitoring of the effects of workplace changes on outcomes, both qualitatively and quantitatively as well as over considerable periods of time. Such research provides insight and suggests hypotheses, but it is difficult to generalize on the basis of its findings (Ichniowski et al. 1996, 303). In contrast, survey-based research, if appropriately conducted, does allow generalization to the population at large. Two reviews of the teamworking literature carried out approximately ten years ago showed that some survey-based research was already in existence (Cohen and Bailey 1997; Guzzo and Dickson 1996), but they also indicated that very little of this empirical work considered issues of overall organizational performance. Indeed, some authors have argued that the evidence regarding the impact of teamwork at the level of the workplace is often based upon anecdotes or descriptive case analyses (Appelbaum et al. 2000, 13; Cohen and Ledford 1994, 13-15). However, over the last decade, studies have begun to emerge that attempt to evaluate group performance at different levels of the organization and to assess the wider benefits of teamwork.

The purpose of this paper is to carry out a critical examination of this literature examining the links between teamworking and performance. Within this, we are particularly interested in identifying studies that look at teamwork as a managerial strategy for the organization of work. The review focuses on studies where both teamwork and performance have been directly captured in a quantitative way. Initially, we identify the various channels through which teamworking can affect performance and the effectiveness outcomes that are likely to result. This theoretical exercise leads to the development of a framework designed to categorize empirical work on effectiveness research and informs a subsequent literature search. The conceptual framework is also used to provide insight into the themes on which a considerable body of work agrees. Further, it enables us to identify the specific problems faced by teamwork-performance research and to produce recommendations on how such research might be conducted in the future.

The rest of the paper is organized as follows. First, we discuss the definitions of both teamwork and performance that will be considered in this review. Next, we formulate specific hypotheses relating to team effectiveness and develop a framework based upon these, which shows how teams can affect organizational outcomes. We then explain the methodology that has been adopted in this review and provide background information on the papers identified. This is followed by a comparison of the results of the individual studies and a detailed discussion of these based upon hypotheses and framework. The final section concludes the paper with a call for quantitative, survey-based research on the teamworkingperformance link to be complemented by more qualitative, case study approaches.

\section{Teamwork and Performance: A Tentative Demarcation of Two Key Notions}

\section{Teamworking}

Over the years, a number of attempts have been made to define teamwork (Hackman 1987; Katzenbach and Smith 1993; Robbins and Finley 1995) and classify teams (Cohen and Bailey 1997; Dunphy and Bryant 1996). However, there remains no generally accepted definition. At different times and in different settings, various terms such as 'teams', 'groups' and 'work units' have been used to describe this form of work organization (Benders and Van 
Hootegem 1999). These terms have frequently been used in conjunction with adjectives such as 'autonomous', 'semi-autonomous', 'selfdirected', 'high-performing' and 'self-managed' (Mueller et al. 2000). This all suggests that working with a specific definition of teamwork would be very restrictive and could exclude studies important for this review. We therefore choose not to adopt a strict definition of 'teamwork' but to work with a 'phenomenological bottom-line' (Schumann et al. 1994). When authors use the words 'team' or 'group' to indicate variables in their research, we consider this as sufficient for their work to be considered for inclusion in our review. Whether a particular reality should be considered as 'teamwork' is therefore left to the individual researcher in the field, and it is important to bear this in mind in the course of this paper (see Van Hootegem 2000, 378).

\section{Performance}

It is also difficult to formulate an unambiguous and definitive description of 'performance', since this ultimately depends upon the objectives of the particular organization. Nevertheless, a wide range of performance indicators have been investigated in organizations, and, for the purposes of this review, we look at these under the headings of operational outcomes and financial outcomes. The former would include productivity (e.g. the number of hours to assemble a car), the quality of the product or service, innovation and customer satisfaction; the latter, value-added per employee and return on capital employed. To complicate matters, many of these indicators can be recorded at different levels within an organization. Productivity, for example, can be measured at department, workplace or company level.

In addition, when one begins to consider the team-based literature, another set of 'performance' outcomes come to the fore (Cohen and Bailey 1997; Guzzo and Dickson 1996). A number of these studies are designed to show the outcomes for individual team members or the team itself. While some of these measures
- job satisfaction, for example, or absenteeism - may not seem directly relevant to the present study, subsequent discussion will show that there are important links with organizational performance. We therefore include such studies within our remit and categorize these measures under the headings of 'attitudinal' and 'behavioural' outcomes.

\section{A Conceptual Framework of Team Effectiveness}

A number of theoretical arguments have been developed to explain why teamworking might lead to improved organizational performance. Some theories focus on the effort and motivation of individual workers and claim that they work harder. Strategic HRM theory, for example, suggests that an appropriately designed HR system, which typically includes teamwork, will have a positive effect on an employee's job satisfaction, commitment and motivation, leading to behavioural changes that result in improved organizational performance (Becker et al. 1997; Dyer and Reeves 1995). Similarly, self-leadership theory focuses on participatory decision-making, individual discretion and teamwork as important motivating factors, and suggests these will lead to more committed employees who strive for greater efficiency and effectiveness (Manz and Sims 1980; Sims and Manz 1996). Work design theory, however, tends to emphasize intra-group processes such as job design, task variety and interdependence (Hackman and Oldham 1980; Wall and Martin 1987), while sociotechnical theory highlights changes in the structure of an organization and its processes as the main mechanism by which performance is enhanced (Mueller et al. 2000; Van Hootegem 2000).

It is apparent from this that the teamworkperformance link is related to the more general discussions surrounding HRM and performance, empowerment, self-leadership and so on. However, teamwork research should not be considered only within these contexts since a specific teamworking literature has emerged 


\section{Teamworking and organizational performance}

over the course of time (Campion et al. 1993; Benders and Van Hootegem 1999; Gladstein 1994; Salas et al. 2000).

Ichniowski et al. (1996, 300-301) provide a summary of the reasons why innovative workplaces may be more effective. We use their framework to address the issue of teamwork, and this forms the basis for the discussion which follows and our subsequent classification of the means by which teamworking could be effective.

- Working harder: Enhancing employee discretion is often held to have a positive effect on job satisfaction and motivation which together result in employees voluntarily working harder. Beyond these effects at the individual level, group dynamics can also play a role: employees may feel stimulated by working together towards a common goal. However, there might also be a downside to working together in that team members may start watching each other very closely. Particularly if a system of collective team reward is implemented, members may exert strong pressure on each other in an attempt to achieve high levels of team performance. A situation where strict norms are imposed and controlled by peers might even result in what has been called group 'terror' or 'tyranny' (Barker 1993; Sinclair 1992). In this situation, peer pressure within teams could be counterproductive for the organization. Employees might experience higher stress levels, with a detrimental effect on team performance. Teams could also enforce norms that restrict effort to a certain maximum, and this would again have performance implications. This so-called 'social loafing' (Karau and Williams 1993; Shepperd 1993) or 'shirking' (Auster 1979) is frequently mentioned in social psychology and organization economics as an explanation for teamworking's negative effect on productivity.

- Working more smartly: Innovative work practices such as teamwork may also lead workers to work more efficiently. In traditional working systems, production problems can only be solved by functional specialists, whereas self-managing teams are capable of solving problems as soon as they occur, thus reducing interruptions to the production process (Salas et al. 2000, 348). In addition, workers often have information that higher management lacks, especially on how to make their own job more efficient (Campion et al. 1993, 826). By encouraging people to express their views and to learn from solving problems, the production process can be improved significantly. Employees may also enjoy using their intellectual capacities, finding work more rewarding as a result.

- Organizational changes: It has also been suggested that the redesign of an organization along team-based lines can involve the rationalization of the production process. Related operations are grouped together, thus allowing more efficient process flows and a reduction in product/information handling (Guzzo and Dickson 1996, 329). The implementation of teamwork simplifies the organizational structure and reduces the need for co-ordination. Decentralizing decision-making to self-directed teams can thus reduce the number of supervisors and middle managers (Ichniowski et al. 1996, 301). Such a redesign can therefore lead to significant improvements in terms of efficiency (e.g. lower costs and throughput times).

Figure 1 attempts to summarize these arguments. Four major dimensions of performance are identified, ranging from individual outcomes to workplace measures of performance. These are: (a) attitudinal outcomes such as job satisfaction, commitment, trust and involvement; (b) behavioural outcomes, including turnover, absenteeism, extra role behaviour and 'concertive' control (Barker 1993); (c) operational outcomes such as productivity, quality of the product or service, innovation and flexibility; and (d) financial outcomes such as added value, added value per employee and profitability. The figure also indicates the potential moderating 


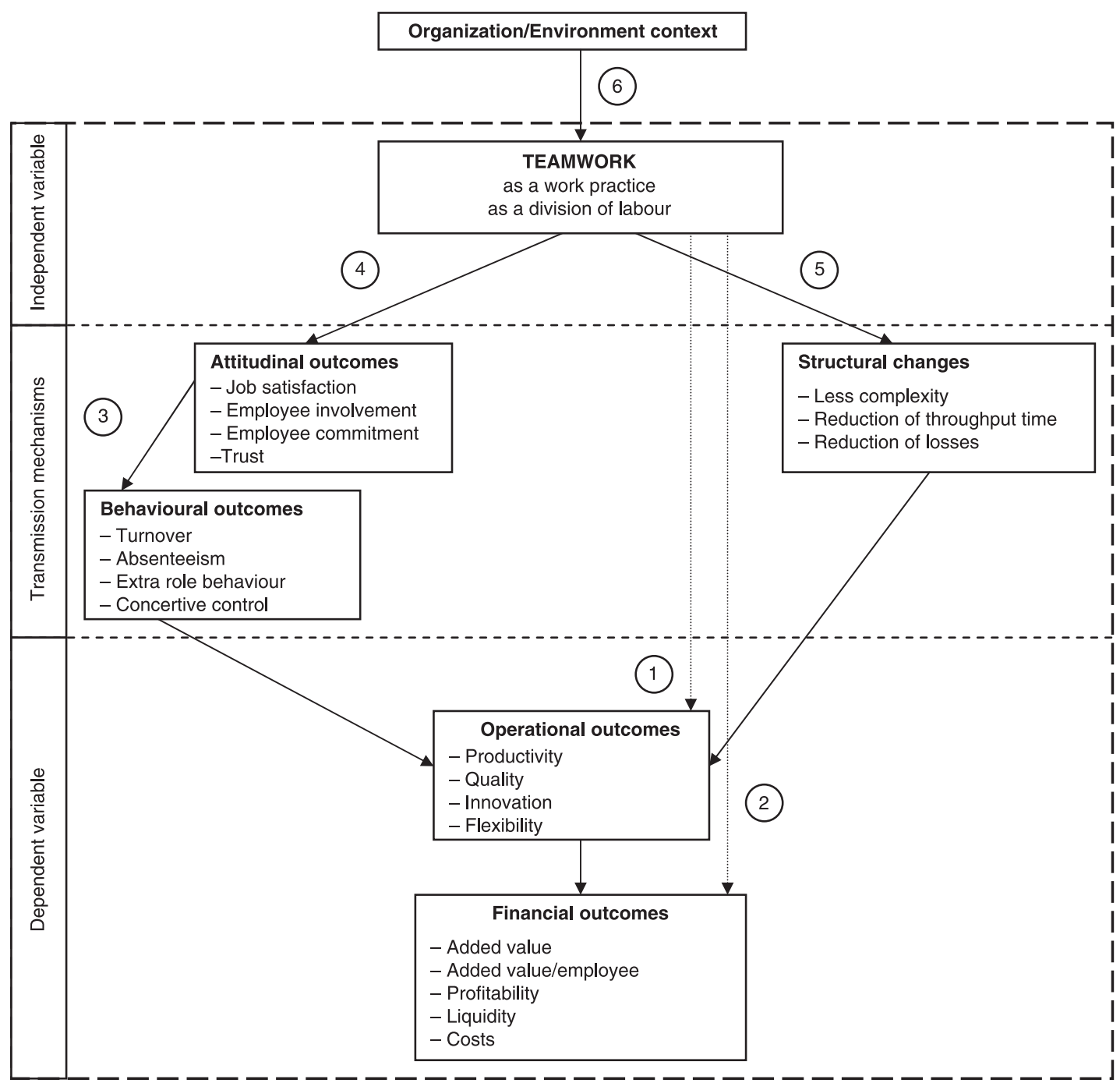

Figure 1. A classification model for studies that analyse the link between teamwork and performance.

role of external factors, allowing for the organization of work to be influenced by workplace characteristics and by environmental and institutional factors. Based upon the preceding discussion as well as the work of other authors (Becker et al. 1997; Dyer and Reeves 1995; Guest 2001), we believe that these dimensions (a to d) can be differentiated into hierarchical layers, with outcomes in one dimension contributing to outcomes in the next (De Winne and Sels 2003). Changes in work organization (the introduction of teams) can have a direct impact on employee behaviour (less absenteeism) and, subsequently, on operational performance (higher productivity), which, in turn, can contribute to higher levels of financial performance (higher profits). One can therefore speak of a 'performance chain' (Dyer and Reeves 1995; Guest et al. 2003). Solid arrows are used to represent possible direct links within this framework, whereas dotted arrows are used to represent indirect links. 


\section{Teamworking and organizational performance}

Figure 1 also helps with the classification of empirical studies looking at the effectiveness of teamwork, as the arrows all indicate relationships that could form the focus of a particular article. Thus the path marked 2 in the figure (from teamworking to financial outcomes) can be the focus of a study, but this does not imply that any effects are direct ones: they would still work through the intermediating variables. It would simply be that the study in question did not look explicitly at these intermediate relationships.

\section{Propositions}

Given the discussion above, we now formulate three specific propositions relating to the teamwork-performance link that will be explicitly examined via our review of the literature.

(a) Teamwork will be positively linked to organizational outcomes. The very general assumption that will guide our review is that teamwork will have positive effects on organizational performance. As previously indicated, the implementation of teams can increase efficiency and encourage employees to work more smartly and harder. We should therefore expect teamwork to have a significant positive impact on operational outcomes such as productivity, quality and flexibility. Since financial outcomes are further down the 'performance chain', they are more likely to be subject to other influences. Hence, although we propose that teamwork will be positively linked to financial outcomes as well, we should expect this relationship to be weaker than the one between teamwork and operational outcomes.

(b) Any positive link between teamworking and performance can be explained by the impact of teamworking on employee attitudes and behaviours and/or organizational structures. Figure 1 shows that there is no direct link from teamwork to organizational outcomes, so any effects on performance would have to work through the two different transmission mechanisms identified. The first of these consists of worker outcomes: teamwork, it is hypothesized, will have a direct impact on the attitudes of the workers (job satisfaction, motivation, commitment), and this will influence their behaviours (turnover, absenteeism). These effects are assumed to be positive, but they could be negative, as both accounts emerge from the literature. The second transmission mechanism has to do with the structural changes that tend to be associated with the implementation of teams. A rationalization of the production process and a reduction in the need for supervision imply that organizations are redesigned to exhibit greater simplicity and efficiency. Team-based working is therefore proposed to be positively associated with structural changes such as a delayering and decentralization.

(c) Organizational and environmental factors will moderate the relationship between teamwork and organizational performance. Finally, it is important to note that, although in general teamwork is expected to have a positive impact, its effects will be moderated by different organizational factors (strategy, size, industry) and environmental aspects (economic climate, labour market).

\section{Scope and Methods}

This paper will review survey-based research published over the last decade that looks at the links between teamwork and the various dimensions of performance shown in Figure 1. In this context, articles will only be included if they contain explicit measures of both teamwork and one or more of the performance outcomes. Furthermore, these articles must present empirical results directly relating to the measures identified. Hence, HRM articles that explicitly identify teamwork and outcome(s) are included, whereas those that make use of 
composite measures of work practices variables (of which teamworking forms a part) are not.

Initially, an extensive literature search was carried out of various online research databases using phrases such as 'teamwork', 'teams', 'groups' and 'high-performance work practices' in combination with keywords such as 'performance' and 'effectiveness'. The snowball method was then applied, going through the reference lists of the selected articles and including additional studies where appropriate. This approach resulted in the identification of over 300 articles but, after further investigation based upon our specific inclusion criteria, this set of studies was reduced to only 31 that look empirically at the links between teamwork and performance. The papers in question are marked with an asterisk in the reference list. These studies all worked with a survey of firms, lines of businesses or plants, making it possible to test any hypotheses specified.

A central assumption of this type of literature review is that the sample of studies identified fairly represents all work done in the field, published and unpublished. As a field matures, journals may tend to accept only articles that report strong effects or statistically significant findings. If this is the case, there could be upward 'publication bias' in the magnitude of reported effects (Rust et al. 1990). This bias could exist in the present paper, although the identification of only 31 relevant articles suggests that this area of study is far from mature.

Table 1 sets out the most important characteristics of the studies we are reviewing. As can be seen, most of the studies surveyed the managers of the establishments (16), with a smaller number focusing on employees (8) or a combination of both types of survey (5). In addition, two studies focused exclusively on existing company records. The surveys can be further classified if we take a look at the research population. First, there are the major surveys that cover private sector (industry-wide) or both private and public sector (economywide) establishments (16), which involve stratified random samples of large- and mediumsized workplaces. Second, there are surveys that concentrate on the effect of work organization on performance in specific industries (7). This focus should ensure that results are comparable across observations since outcomes, work practices and control variables can be more precisely measured. The approach also enriches the quantitative analyses with the author's detailed knowledge of the industry's history, technology, industrial relations and product market (Ichniowski et al. 1996). However, concentration on a single industry makes it difficult to generalize the results to other settings. A number of studies narrow their focus further and look only at different plants of one company or even different production lines within one firm (7). Finally, there is one survey that examines the link between work organization and performance in more than one country.

The last column of Table 1 indicates whether the study has a longitudinal or a cross-sectional design. It can be seen that eight studies analyse multiple periods of data. In non-experimental studies, cross-sectional data make it very difficult to determine causality and to rule out the possibility that omitted variables have an influence on the result (Leamer 1983). The advantage of panel data is that they provide information on changes, which is necessary for estimating fixed-effects models. However, there can be a 'time lag' problem, whereby the reorganization of work takes some time and a plant may still be in transition when the outcomes are measured. In many cases, the implementation phase of the change can be accompanied by a decline in performance due to the costs of associated measures (such as extra training) or because of resistance from the employees. This means that it is not clear precisely when the performance measurement should be carried out.

It is beyond the scope of this paper to review in detail all the different variables that were analysed in each study, but we still wish to take a closer look at the way in which the independent and dependent variables were operationalized. These findings are summarized in Tables 2 and 3, respectively. 
Table 1. Methodology

\begin{tabular}{|c|c|c|c|c|c|}
\hline & & Type of methodology used & Research population & Country & $\begin{array}{l}\text { Longitudinal/ } \\
\text { cross-sectional }\end{array}$ \\
\hline 1 & Bacon and Blyton 2000 & Survey of workers (union representatives) & Iron and steel industry & Britain & Cross-sectional \\
\hline 2 & Banker et al. 1996 & Survey of company records & Electromechanical assembly plant & US & Longitudinal \\
\hline 3 & Batt 1999 & Survey of employees and company records & Telecommunications company & US & Cross-sectional \\
\hline 4 & Batt 2001 & Survey of employees and company records & Telecommunications company & US & Cross-sectional \\
\hline 5 & Batt 2004 & Survey of employees & Telecommunications company & US & Cross-sectional \\
\hline 6 & Batt and Appelbaum 1995 & Survey of employees & Telecommunications and apparel companies & US & Cross-sectional \\
\hline 7 & Benders et al. 1999 & Survey of managers & Economy-wide & 10 EU countries & Cross-sectional \\
\hline 8 & Black and Lynch 2001 & Survey of managers & Industry-wide & US & Longitudinal \\
\hline 9 & Boning et al. 2001 & Survey of managers and employees & Steel mills & US & Longitudinal \\
\hline 10 & Cappelli and Neumark 2001 & Survey of managers & Industry-wide & US & Longitudinal \\
\hline 11 & Cohen et al. 1996 & Survey of managers and employees & Telephone company & US & Cross-sectional \\
\hline 12 & Cooke 1994 & Survey of managers & Industry-wide & US & Cross-sectional \\
\hline 13 & Delarue et al. 2004 & Survey of managers & Economy-wide & Belgium & Cross-sectional \\
\hline 14 & DeVaro 2006 & Survey of managers & Economy-wide & Britain & Cross-sectional \\
\hline 15 & Dunlop and Weil 1996 & Survey of managers & Apparel industry & US & Cross-sectional \\
\hline 16 & Elmuti 1997 & Survey of managers & Industry-wide & US & Cross-sectional \\
\hline 17 & Glassop 2002 & Survey of managers & Economy-wide & Australia & Cross-sectional \\
\hline 18 & Godard 2001 & Survey of employees & Economy-wide & Canada & Cross-sectional \\
\hline 19 & Harley 2001 & Survey of managers and employees & Economy-wide & Britain & Cross-sectional \\
\hline 20 & Hamilton et al. 2003 & Survey of company records & Textile manufacturer & US & Longitudinal \\
\hline 21 & Ichniowski et al. 1997 & Survey of managers and company records & Steel finishing lines & US & Longitudinal \\
\hline 22 & Mathieu et al. 2006 & Survey of employees & Office equipment company & Canada & Cross-sectional \\
\hline 23 & McNabb and Whitfield 1997 & Survey of managers & Economy-wide & Britain & Cross-sectional \\
\hline 24 & Osterman 2000 & Survey of managers & Industry-wide & US & Longitudinal \\
\hline 25 & Paul and Anantharaman 2003 & Survey of managers and employees & Software companies & India & Cross-sectional \\
\hline 26 & Power and Waddell 2004 & Survey of managers & Economy-wide & Australia & Cross-sectional \\
\hline 27 & Procter and Burridge 2004 & Survey of managers & Economy-wide & Britain & Cross-sectional \\
\hline 28 & Stewart and Barrick 2000 & Survey of employees & Industry-wide & US & Cross-sectional \\
\hline 29 & Tata and Prasad 2004 & Survey of managers and employees & Industry-wide & US & Cross-sectional \\
\hline 30 & West et al. 2002 & Survey of managers & Acute hospitals & Britain & Cross-sectional \\
\hline 31 & Zwick 2004 & Survey of managers & Industry-wide & Germany & Longitudinal \\
\hline
\end{tabular}


Table 2. Types of independent variables studied

\begin{tabular}{|c|c|c|c|c|c|}
\hline & & Label for teams & $\begin{array}{l}\text { Definition/description } \\
\text { of teamwork }\end{array}$ & $\begin{array}{l}\text { Features } \\
\text { of teams }\end{array}$ & $\begin{array}{l}\text { Organizational } \\
\text { and/or external factors }\end{array}$ \\
\hline 1 & Bacon and Blyton 2000 & Teams - high road and low road teams & Description pp.1436-1438 & Yes & No \\
\hline 2 & Banker et al. 1996 & High-performance work teams & Description pp.873-876 & No & Yes \\
\hline 3 & Batt 1999 & Self-managed teams & Description p.542 & Yes & Yes \\
\hline 4 & Batt 2001 & Self-managed teams & Description pp.4-5 & No & Yes \\
\hline 5 & Batt 2004 & Self-managed teams & Description pp.186-187 & No & Yes \\
\hline 6 & Batt and Appelbaum 1995 & Self-managed teams & Description pp.358 and 361 & Yes & Yes \\
\hline 7 & Benders et al. 1999 & Team-based work & Definition p.13 & Yes & No \\
\hline 8 & Black and Lynch 2001 & Self-managed teams & - & No & Yes \\
\hline 9 & Boning et al. 2001 & Problem-solving teams & - & No & Yes \\
\hline 10 & Cappelli and Neumark 2001 & Self-managed or autonomous teams & Definition p.748 & No & No \\
\hline 11 & Cohen et al. 1996 & Self-managing work teams & Definition p.653 & Yes & No \\
\hline 12 & Cooke 1994 & Work teams & - & No & Yes \\
\hline 13 & Delarue et al. 2004 & Teams - lean/sociotechnical teams & Definition p.17 & No & Yes \\
\hline 14 & DeVaro 2006 & Team production & - & Yes & Yes \\
\hline 15 & Dunlop and Weil 1996 & Modular production groups & Description p.338 & No & Yes \\
\hline 16 & Elmuti 1997 & Self-managed teams & Definition p.185 & No & No \\
\hline 17 & Glassop 2002 & Self-managing work groups & Definition p.227 & No & No \\
\hline 18 & Godard 2001 & Teams & Definition p.786 & Yes & Yes \\
\hline 19 & Harley 2001 & Autonomous teams & Description p.729 & No & Yes \\
\hline 20 & Hamilton et al. 2003 & Modular production teams & Description pp.475-476 & No & No \\
\hline 21 & Ichniowski et al. 1997 & Team-based work organization & Definition p.294 & No & Yes \\
\hline 22 & Mathieu et al. 2006 & Empowered teams & Description p.101 & Yes & Yes \\
\hline 23 & McNabb and Whitfield 1997 & Teamworking & - & No & Yes \\
\hline 24 & Osterman 2000 & Self-managed teams & - & No & Yes \\
\hline 25 & Paul and Anantharaman 2003 & Teamwork & Description p.1251 & No & Yes \\
\hline 26 & Power and Waddell 2004 & Self-managed work teams & Description pp.249-250 & No & No \\
\hline 27 & Procter and Burridge 2004 & Teamwork - semi-autonomous teams & Description pp.15-17 & Yes & Yes \\
\hline 28 & Stewart and Barrick 2000 & Work teams & Description p.140 & Yes & No \\
\hline 29 & Tata and Prasad 2004 & Self-managed teams & Description p.254 & Yes & No \\
\hline 30 & West et al. 2002 & Teams & - & No & Yes \\
\hline 31 & Zwick 2004 & Shop-floor employee participation - teamwork & Description p.720 & No & Yes \\
\hline
\end{tabular}




\section{Teamworking and organizational performance}

Table 3. Types of outcomes measured

\begin{tabular}{|c|c|c|c|c|c|c|c|}
\hline & & $\begin{array}{l}\text { Number of } \\
\text { measures }\end{array}$ & $\begin{array}{l}\text { Operational } \\
\text { outcomes }\end{array}$ & $\begin{array}{l}\text { Financial } \\
\text { outcomes }\end{array}$ & $\begin{array}{l}\text { Behavioural } \\
\text { or attitudinal } \\
\text { outcomes }\end{array}$ & $\begin{array}{l}\text { Structural } \\
\text { changes }\end{array}$ & $\begin{array}{l}\text { Objective / } \\
\text { subjective } \\
\text { measures }\end{array}$ \\
\hline 1 & Bacon and Blyton 2000 & More than 3 & $x$ & & $x$ & $\mathrm{x}$ & Subjective \\
\hline 2 & Banker et al. 1996 & 2 & $x$ & & & & Objective \\
\hline 3 & Batt 1999 & 2 & $x$ & & & & Both \\
\hline 4 & Batt 2001 & More than 3 & $x$ & $x$ & & $x$ & Objective \\
\hline 5 & Batt 2004 & 3 & & & $x$ & & Subjective \\
\hline 6 & Batt and Appelbaum 1995 & 3 & $x$ & & $x$ & & Subjective \\
\hline 7 & Benders et al. 1999 & More than 3 & $x$ & $x$ & $x$ & $x$ & Subjective \\
\hline 8 & Black and Lynch 2001 & 1 & $x$ & & & & Objective \\
\hline 9 & Boning et al. 2001 & 1 & $x$ & & & & Objective \\
\hline 10 & Cappelli and Neumark 2001 & 3 & $x$ & $x$ & & & Objective \\
\hline 11 & Cohen et al. 1996 & More than 3 & $x$ & $x$ & $x$ & & Subjective \\
\hline 12 & Cooke 1994 & 1 & & $x$ & & & Objective \\
\hline 13 & Delarue et al. 2004 & More than 3 & $x$ & & $x$ & & Both \\
\hline 14 & DeVaro 2006 & 1 & & $x$ & & & Subjective \\
\hline 15 & Dunlop and Weil 1996 & 2 & $x$ & $\mathrm{X}$ & & & Objective \\
\hline 16 & Elmuti 1997 & More than 3 & $x$ & $x$ & $\mathrm{X}$ & & Subjective \\
\hline 17 & Glassop 2002 & More than 3 & $x$ & $x$ & $x$ & $x$ & Subjective \\
\hline 18 & Godard 2001 & More than 3 & & & $\mathrm{x}$ & & Subjective \\
\hline 19 & Harley 2001 & More than 3 & & & $\mathrm{X}$ & & Subjective \\
\hline 20 & Hamilton et al. 2003 & 2 & $x$ & & & & Objective \\
\hline 21 & Ichniowski et al. 1997 & 2 & $x$ & & & & Objective \\
\hline 22 & Mathieu et al. 2006 & 2 & $x$ & & & & Both \\
\hline 23 & McNabb and Whitfield 1997 & 1 & & $x$ & & & Subjective \\
\hline 24 & Osterman 2000 & 1 & & & & $\mathrm{x}$ & Objective \\
\hline 25 & Paul and Anantharaman 2003 & More than 3 & $x$ & $x$ & & & Both \\
\hline 26 & Power and Waddell 2004 & 1 & $x$ & & & & Subjective \\
\hline 27 & Procter and Burridge 2004 & 3 & $x$ & $x$ & & & Subjective \\
\hline 28 & Stewart and Barrick 2000 & 1 & $x$ & & & & Subjective \\
\hline 29 & Tata and Prasad 2004 & 1 & $x$ & & & $\mathrm{x}$ & Subjective \\
\hline 30 & West et al. 2002 & More than 3 & $x$ & & & & Objective \\
\hline 31 & Zwick 2004 & 1 & & $\mathrm{x}$ & & $x$ & Objective \\
\hline
\end{tabular}

\section{Definition and Measurement of Teamwork}

As indicated previously, divergent work forms may all be called 'teamwork'. Further information on structural features is therefore required in order to determine the type of group work identified. In most of the articles, teamwork was based on the delegation of responsibilities to employees and decentralized decision-making. While some of the studies in our review are based on sociotechnical or work design theory, thus emphasizing teamwork and task design as the direct predictors of performance, others take strategic HRM theory as their starting point, defining teamwork or employee participation as one item in a list of possible 'innovative work practices' that can be introduced to enhance the ability of the human resources in organizations to contribute to organizational performance (Doorewaard et al. 2002).

The third column of Table 2 gives an overview of the labels of the independent variables used in the 31 studies. It is striking that only a minority of the studies give a clear, explicit definition of teamwork. A number of authors only give a (sometimes rather vague or implicit) description of what they associate with a 'team'. In the studies from the HRM tradition, teamwork is usually only one component of a series of measures designed to improve employee involvement and participation, with little specification of the type of work 
organization that underpins them. Two examples from studies that do give a definition of teamwork also show that such definitions are not always the same:

A self-managing work group is a group of interdependent individuals that have accepted responsibility for a group task and share this responsibility by monitoring and controlling the contributions of its members. (Glassop 2002, 227)

Self-managed or autonomous teams give their members authority over decisions that in other contexts are made by supervisors, such as how to perform their tasks or, in more advanced situations which tasks to perform. (Cappelli and Neumark 2001, 748)

These definitions do have some similarities, but the differences in emphasis suggest that there is no one-on-one relation between what is called a 'team' and the organizational work form that the term is designed to represent. Teamwork is not a unitary phenomenon; the semantic notion covers different ontological realities.

A number of authors have made pleas for a more differentiated model of team design. Some criteria for classification that have been suggested are the degree of self-management, the nature of the team membership, the team structure (size, breadth of job definition of the team members, degree of autonomy) and composition, the type of tasks performed and the technology and equipment used (Dunphy and Bryant,1996, 678; Cohen and Bailey 1997, 248). Taking into account these team characteristics, a typology of teamwork could be developed, making it possible to re-express the initial research question, 'Does teamwork increase organizational performance?' as 'Which type of teams generates which organizational outcomes?' However, our review shows that, to measure the presence of teamwork, most studies are satisfied with a yes/no response or a percentage of employees working in a team system. In Table 2, we indicate the studies that do include some features of teams in their analysis. It should be noted that only one study makes reference to team type (Ichniowski et al. 1997) and only two to team size (Banker et al. 1996; Elmuti 1997), with none of these having an explicit measure in their analysis. Instead, 'features' usually refers to aspects of autonomy.

\section{Definition and Measurement of Performance}

Various performance outcomes are measured in the 31 studies identified, with 15 of the articles employing three or more measures of effectiveness. Ten studies focus only on one (operational or financial) outcome. In the other six, two indicators of organizational performance are examined. Operational outcomes are included in almost every study, as an attempt to measure the direct link between teamwork and organizational performance. Few studies try to make the picture more complete by focusing on transmission mechanisms. Only ten studies analysed worker outcomes, the most common being absenteeism, turnover and job satisfaction. Even more exceptional are studies that pay attention to structural changes.

We can make a distinction between, on the one hand, studies that featured objective measures of performance often taken from production records and, on the other, those that rely on perceptions of performance, derived from interviews or from the responses of employees or managers to survey questions. Examples of objective outcomes are monthly defect rates (Banker et al. 1996), quality measured as the percentage of tons produced that meet specific quality standards (Ichniowski et al. 1997) and weekly productivity measured as the hours required to produce a batch of garments (Hamilton et al. 2003). Subjective information on performance outcomes is provided either by one of the parties involved (for example, when a respondent is asked to compare the quality of their product or service with other establishments in the same industry) (Procter and Burridge 2004) or as work team effectiveness rated by the team members and team managers (Cohen et al. 1996). 


\section{Teamworking and organizational performance}

Table 4. Results

\begin{tabular}{|c|c|c|c|c|c|}
\hline & & $\begin{array}{l}\text { Behavioural or } \\
\text { attitudinal outcomes }\end{array}$ & $\begin{array}{l}\text { Structural } \\
\text { changes }\end{array}$ & $\begin{array}{l}\text { Operational } \\
\text { outcomes }\end{array}$ & $\begin{array}{l}\text { Financial } \\
\text { outcomes }\end{array}$ \\
\hline 1 & Bacon and Blyton 2000 & + & + & + & \\
\hline 2 & Banker et al. 1996 & & & + & \\
\hline 3 & Batt 1999 & & & + & \\
\hline 4 & Batt 2001 & & + & + & + \\
\hline 5 & Batt 2004 & + & & & \\
\hline 6 & Batt and Appelbaum 1995 & + & & + & \\
\hline 7 & Benders et al. 1999 & + & + & + & + \\
\hline 8 & Black and Lynch 2001 & & & 0 & \\
\hline 9 & Boning et al. 2001 & & & + & \\
\hline 10 & Cappelli and Neumark 2001 & & & 0 & 0 \\
\hline 11 & Cohen et al. 1996 & + & & + & + \\
\hline 12 & Cooke 1994 & & & & + \\
\hline 13 & Delarue et al. 2004 & + & & 0 & \\
\hline 14 & DeVaro 2006 & & & & + \\
\hline 15 & Dunlop and Weil 1996 & & & + & + \\
\hline 16 & Elmuti 1997 & + & & + & + \\
\hline 17 & Glassop 2002 & + & + & + & 0 \\
\hline 18 & Godard 2001 & + & & & \\
\hline 19 & Harley 2001 & 0 & & & \\
\hline 20 & Hamilton et al. 2003 & & & + & \\
\hline 21 & Ichniowski et al. 1997 & & & 0 & \\
\hline 22 & Mathieu et al. 2006 & & & + & \\
\hline 23 & McNabb and Whitfield 1997 & & & & 0 \\
\hline 24 & Osterman 2000 & & + & & \\
\hline 25 & Paul and Anantharaman 2003 & & & + & + \\
\hline 26 & Power and Waddell 2004 & & & 0 & \\
\hline 27 & Procter and Burridge 2004 & & & + & + \\
\hline 28 & Stewart and Barrick 2000 & & & + & \\
\hline 29 & Tata and Prasad 2004 & & + & + & \\
\hline 30 & West et al. 2002 & & & + & \\
\hline 31 & Zwick 2004 & & + & & + \\
\hline
\end{tabular}

Notes: + indicates a statistically significant impact and/or performance enhancing effect. 0 indicates no statistically significant effect.

There may appear to be advantages in having objective measures, but the accountancy protocols on which financial indicators are based have come under critical scrutiny in the wake of a number of corporate scandals (Guest et al. 2003, 294). Similarly, subjective measures have been subject to some criticism (Starbuck and Mezias 1996), but they may have the advantage of being both more up to date (Hart and Banbury 1994) and more comparable across industries (Covin et al. 1994). The last column of Table 3 shows a rough balance between objective and subjective measures, with a limited number of studies making use of both.

\section{Teams and Performance: What Can We Learn from Empirical Studies?}

Over the last decade, considerable progress has been made in understanding team effectiveness. The results from our set of studies reveal a number of significant findings which will be classified according to the relationships shown in Figure 1. The numbers below correspond to the numbers shown in this figure. Table 4 shows specific results related to each of the papers identified. All the articles present statistical analysis related to their data. Sample sizes vary substantially, but this type of analysis allows for such differences. Furthermore, almost 
all the articles have been deemed to be of publishable standard by independent referees. Hence, we attempt to draw conclusions on the basis of the evidence presented in this set of 31 papers.

\section{Teamwork and Operational Outcomes: (1)}

A positive relationship between teamwork and operational performance is found in a number of studies. In their study of a textile manufacturer, Hamilton et al. (2003) found that team-sewing increased productivity by approximately $18 \%$. According to Cohen et al. (1996), a form of work organization incorporating teams and strong employee involvement had a significant impact on both quality and efficiency. Reducing the number of management layers, working with flexible job descriptions and the introduction of teamworking were all positively associated with different operational outcomes in the study of Bacon and Blyton (2000). West et al. (2002) focused on HR effectiveness in acute hospitals using health outcomes as operational measures, and found a significant relationship between teamworking and reduced patient mortality. An improvement in both quality and labour productivity was also recorded by Banker et al. (1996), Batt (1999), Batt (2001), Benders et al. (1999), Elmuti (1997), Mathieu et al. (2006), Paul and Anantharaman (2003), Procter and Burridge (2004), Stewart and Barrick (2000) and Tata and Prasad (2004). Positive productivity effects were found in studies relating to the Australian economy (Glassop 2002), US steel mills (Boning et al. 2001) and the US apparel industry (Dunlop and Weil 1996). Finally, Batt and Applebaum (1995) report improved quality.

However, little or no statistically significant evidence of beneficial productivity effects was found in five studies. A study that linked the work organization of Flemish firms to different performance indicators (Delarue et al. 2004) found no relationship between the application of teamwork and labour productivity, although positive correlations with innovation and personnel fit were registered. Ichniowski et al.
(1997) found that bundles of HRM practices had a significant impact on performance, but teamwork did not when considered in isolation. Similarly, Power and Waddell (2004) found that, although empowerment had a significant effect, this was not true of their measure of self-managed work teams. Both Black and Lynch (2001) and Cappelli and Neumark (2001) found little evidence of positive productivity effects in their industry-wide studies, although it should be noted that this lack of significance applied to a number of the independent variables used in their studies (including bundles of work practices).

With no studies indicating a negative effect and 18 out of the 23 that measured operational outcomes finding beneficial effects, we can say that, in general, teamwork is likely to have a positive impact on operational performance. This confirms our first proposition - an interesting, if not entirely unexpected, result. Although the research settings are different and the studies measure teamwork and organizational outcomes in different ways, a degree of consistency emerges in their findings.

\section{Teamwork and Financial Outcomes: (2)}

We might expect a weaker link with financial outcomes than with operational outcomes, since factors other than teamwork can affect the former. Nevertheless, the overall pattern of relationships between teamwork and financial measures is consistent with the assumption that teamwork is an effective practice in increasing the competitiveness of firms. Cooke (1994) found that teamwork had a significant impact on value added per employee. Similarly, Zwick (2004) found that the introduction of shop floor participation, in which teamwork formed a substantial part, significantly increased economic value added in German firms. Teamwork also proved a positive predictor of financial performance in the studies of Batt (2001), Benders et al. (1999), Cohen et al. (1996), DeVaro (2006), Dunlop and Weil (1996), Elmuti (1997), Paul and Anantharaman (2003) and Procter and Burridge (2004). 


\section{Teamworking and organizational performance}

Only three studies in our sample found no significant association between teamwork and financial outcomes. Glassop (2002) tried to measure the effect of self-managing work groups on profitability, but the results were inconclusive at the 5\% significance level. Similarly, McNabb and Whitfield (1997) found the impact of teamworking on relative financial performance to be significant only at the $10 \%$ level. Cappelli and Neumark (2001) found their various measures of teamwork had no effect on revenue per worker. Their careful conclusion is that high-performance work practices tend to raise both productivity and worker compensation, with the net effect on overall profitability being unclear.

These results give support to the proposition that teamwork has positive effects on financial outcomes. The three insignificant results can perhaps be explained by the fact that financial outcomes work through intermediate variables rather than there being any direct effect.

\section{Teamwork and Worker Outcomes:}

(3) and (4)

Attitudinal or behavioural outcomes at the employee level were measured in ten studies. Godard's (2001) survey of Canadian employees focused exclusively on this type of outcome. He examined whether work practices associated with the high-performance model have mainly negative or positive implications for workers. He found that team-based work has strong and statistically significant positive correlations with belongingness, task involvement, job satisfaction, empowerment, commitment and citizenship behaviour. However, the results for team autonomy and responsibility were generally insignificant. Batt (2004), Batt and Appelbaum (1995) and Elmuti (1997) found that the job design characteristics associated with self-managed teams significantly improve job satisfaction and organizational commitment. A similar result was found by Bacon and Blyton (2000), who showed that workers under 'highroad' teamworking scored more positively on motivation, interest in their job and enjoyment of the job. Benders et al. (1999), Cohen et al. (1996) and Delarue et al. (2004) all found that the large-scale use of group work leads to lower levels of absenteeism, whereas the study by Glassop (2002) found that firms with teams had lower levels of employee turnover.

This provides a summary of reported positive employee outcomes, but it is also possible that teamwork might cause negative employee experiences. A team-based work organization can intensify 'concertive' control (Barker 1993) and workload. A few of the studies explicitly looked at this issue, but no such results emerged. Harley (2001) reported no significant differences between team members and nonteam members in terms of their reported levels of stress, satisfaction and commitment. Overall, therefore, these results suggest that the impact of teamwork on employee attitudes (e.g. motivation, commitment) and behaviour (e.g. turnover, absenteeism) is largely positive.

\section{Teamwork and Structural Changes: (5)}

Only a few of the studies in our review operationalized structural changes as an outcome associated with the introduction of teamwork. However, such changes can imply a reduction in the complexity of the production process and in the need for co-ordination. In their European study, Benders et al. (1999) recorded a reduction of the throughput time as one of the positive effects of team-based work. Both Dunlop and Weil (1996) and Hamilton et al. (2003) report an impact on production lead time, although in both studies this variable was considered as part of 'operational performance'. Another aspect of the organization that can be influenced by teamwork is hierarchical structure. Decentralizing decisionmaking to the lowest level in organizations can mean that there is less need for managers and supervisors. Bacon and Blyton (2000) indicate that a reduction in the number of management layers was an important reason for the introduction of teamwork. Tata and Prasad (2004) present results that show that team 
effectiveness is increased when teamwork is combined with a decentralized structure; and Zwick (2004) shows that a combination of teamwork and a flatter organizational structure has an additional positive effect upon profitability. Glassop (2002) found that firms that work with self-managing work groups have a broader span of control, thus being less hierarchical. Similarly, Batt (2001) found that the execution of supervisory tasks by workers increased with the existence of self-managed teams. Finally, Osterman (2000) reports that teamwork is positively and significantly related to establishment layoffs, with these layoffs falling disproportionately upon managers. These results suggest that, when teamwork is associated with structural change, performance can be further enhanced, but there is insufficient evidence to conclude that this is a widespread phenomenon.

\section{The Link Between Teamwork and Performance, Controlling for Organizational and Environmental Factors: (6)}

The majority of the studies used regression techniques to estimate the impact of teamwork on performance, and included in their models such organizational characteristics as size of the establishment, age of the plant, product diversity and features of the workforce as controls. Apart from these typical control variables, some authors suggested that work practices such as teamwork would be more effective when 'bundled' with supporting management practices. The reasoning behind this is that workers cannot make good decisions without sufficient information and training, and they are thus unlikely to make suggestions for improvement if they feel this will cost them their jobs or reduce their pay (Ichniowski et al. 1996, 302).

In this context, reward has been seen as an important variable moderating the teamworkperformance link. Gain-sharing, profit-sharing and other programmes that provide employees with a share in improved performance are typically seen as strongly complementary to the introduction of teamwork. 'Compensation' in one form or another is included in ten studies in our review, but the evidence is far from clear cut. Boning et al. (2001), Cappelli and Neumark (2001) and Hamilton et al. (2003) all show that teamwork is associated with greater levels of worker compensation. Tata and Prasad (2004) indicate that team reward has a positive and significant impact on effectiveness. Similarly, Ichniowski et al. (1997) argue that it is important to analyse a firm's work policies as a part of a coherent incentive system. The results of their study in the steel industry show that systems of HRM practices, including an incentive-pay plan, determine productivity and quality, while marginal changes in individual work practices have little effect. Cooke (1994) shows that teamwork and group-based incentives yield substantial gains in firm-level performance (measured as value added net of labour costs per employee), although other results in the same paper suggest little difference between bundles and individual practices. In contrast, both Batt and Applebaum (1995) and Osterman (2000) find that teamwork is associated with lower pay levels. The former also find that compensation has no effect on performance, with this result being supported by other work undertaken by one of the authors (Batt 1999, 2001).

Another organizational characteristic that comes to the fore in some studies is strategy. For example, the hypothesis of Dunphy and Bryant (1996) that low-intensity teamworking impacts principally on cost, whereas semiautonomous teamworking impacts on value, was tested by Procter and Burridge (2004). There appears to be some tentative evidence that, although cost-focused firms achieve higher levels of financial performance when they adopt semi-autonomous teamworking, it is teamworking per se that has an impact on performance in value-focused establishments. Strategy is also a moderating variable in the research of Delarue et al. (2004).

An institutional factor that often appears (mostly in the US) is the existence or level of 


\section{Teamworking and organizational performance}

unionization. Cooke (1994) examined whether union representation positively or negatively influences the effectiveness of employee participation programmes and group-based incentives. He found that unionized firms, on average, provide a better environment for tapping the benefits of employee participation programmes than do non-union firms. Union affiliation was also included in the analyses undertaken by Batt and Appelbaum (1995), Black and Lynch (2001), Godard (2001), Harley (2001) and Ichniowski et al. (1997).

\section{Discussion and Suggestions for Future Research}

\section{Main Findings}

The results of this literature review generally point in one direction: adopting team structures can yield positive outcomes for organizations. In terms of our specific propositions, we can say the following:

Proposition A. Teamwork will be positively linked to organizational outcomes: Confirmed. Most of the studies that analysed the relationship between teamwork and operational or financial outcomes found a positive link.

Proposition B. Any positive link between teamworking and performance can be explained by the impact of teamworking on employee attitudes and behaviours and/or organizational structure: Confirmed. Almost all the studies that analysed the link with behavioural and attitudinal outcomes at the level of the employees found that worker outcomes improved. The results with regard to structural change also suggest a positive impact.

Proposition C. Organizational and environmental factors will moderate the relationship between teamwork and organizational performance: Confirmed. The studies in the review offer support to the idea that contextual factors act to moderate the teamwork-performance link.

\section{Methodological Issues}

Before assessing the implications of these findings, a word of caution is necessary with regard to terms such as 'effects' or 'impact'. We can look at this in the context of the recent move in the HRM-performance literature towards specific consideration of issues of causality. The statistically significant relationships between HRM practices and company performance which are presented in the literature evoke difficult 'chicken or egg' questions (Sels 2002, 6). It is unclear what comes first: do HRM practices cause good performance or does good performance lead to the implementation of certain HRM practices? The results of a study by Guest et al. (2003), for example, on the effect of HRM on corporate performance in the UK, supported the view that profitability creates scope for more HRM. Thus, while the results reveal a positive association between HRM and profitability, they do not support the causality assumption that HRM leads to the higher profitability.

However, it can be argued that this causality dilemma is less pertinent here, as the analogy with teamwork research only holds to a certain extent. Why would a high-performing organization invest their profits in a redesign of the production process when they are selfevidently being well-served by the existing one? Moreover, the implementation of an alternative work system such as teamwork would be costly in terms of both money and time. In this context, it therefore seems implausible that causality would run in the opposite direction.

\section{Future Research}

This final section attempts to contribute to ongoing research looking at the team-performance link by highlighting some important gaps that future studies could address.

Embeddedness in a 'division of labour' approach. A distinction should be made between, on the one hand, decisions in organizations that lead to workplace change and, on 
the other, decisions that have an impact on employment relations. In management terms, this difference can be translated into operations management versus HR management. Teamwork should not only be considered as an aspect of the HR system, nor simply as a redesign that can be undertaken in a vacuum, but rather as a dimension of the division of labour as well. The way in which jobs are designed is strongly embedded in choices made at higher levels of the organization in areas such as production organization, work organization and technological choice. Few of the studies in the review focus on this broader context. However, decisions which are made at these levels exclude some options concerning the design of teams. The decision of an organization to work with a line-oriented production system, for example, will strongly determine the type of teamwork it can adopt.

Structural features of teams as inputs to a team typology. A second important issue is that a lot of the existing research examines the effect of the implementation of teamwork per se on performance, without taking into account the structural features of the teams, such as task design or the degree of autonomy and self-leadership. We recommend that these 'independent variables' should be elaborated upon in future research and that more complete descriptions of the technology, task and products/services associated with the teams should be provided.

It seems appropriate to classify teams in an autonomy-interdependence matrix. At one extreme of this matrix would be a group of workers, which may be called a team, but have no job enrichment or reciprocal interdependence because preparing, supporting and regulating tasks remain concentrated at the management level. At the other extreme would be a self-leading team whose members have a large range of responsibilities, a high degree of interdependence and identify with team targets. The team leader's role in this case would be to facilitate the team's selfmanaging capacity. Between these two extremes, there could be various intermediate forms, some with low autonomy and high interdependence and others with high autonomy and low interdependence.

Team development as a necessary complement to team design. Most studies still do not address how teams change over time. It is important to recognize the association between team evolution, team structure and performance improvements. Teams in the first stage of their development process can exhibit different structural features from mature teams. Ancona et al. (2001) make a call to sharpen the temporal perspective on conducting organizational research. The constitution of a teamperformance link has to be seen as a process in time, and hence an indicator of team maturity is indispensable. Only three studies in our review include such an indicator in their model of team effectiveness (Banker et al. 1996; Glassop 2002; Hamilton et al. 2003).

Teamwork as only one element of a bundle of practices. Teamwork should also be considered not in isolation, but as one item in a system which, if appropriately configured, can reap benefits through interactive and mutually reinforcing effects. Such systems could include employee involvement schemes, training and development programmes, and forms of profit sharing (Ramsay et al. 2000, 502). The interaction between teamwork and these other elements should be further examined to give us a better understanding of how teamwork contributes to organizational performance.

Need for a contingency approach. There is also a need to take into account in more detail the organization and industry in which teams are embedded and the objectives that underpin operations. Management strategy, market position, competitiveness and the broad economic situation may be important moderating conditions in explaining how teams can positively influence organizational productivity. In addition, internal contingencies must be considered. It is not the management-employment 


\section{Teamworking and organizational performance}

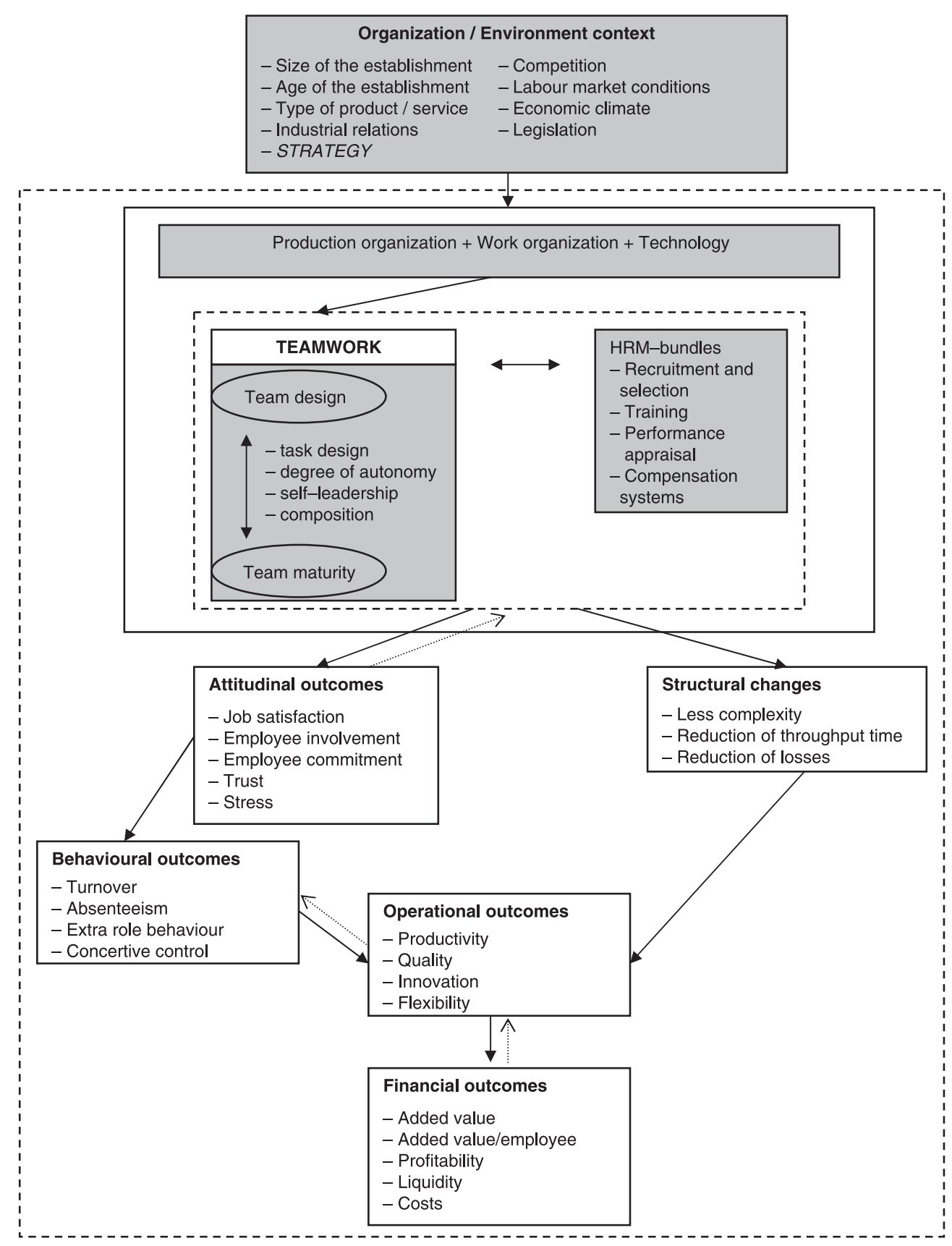

Figure 2. The relationship between teamwork and performance: refinement of the model.

relationship (HR policy) or the structure of the division of labour (work system) alone that influences the performance of an organization, but the interaction between the two.
Most of the studies we have reviewed here remain 'black box' research. The most important conclusion of this review is that, although there is a positive association between teamworking 
and performance, the nature of this link has not been definitively established. Therefore, we make a plea for more complex model building to address the issue of how teams contribute to organizational performance. A first step is a more differentiated model of team design, team development and team performance measurement. There is some evidence to suggest that the conventional link between teamworking and performance (through job design and motivation) does work, but there needs to be a lot more exploration of the linkage that operates through structural changes.

The results of this review as well as the discussion concerning the direction of future research suggest that our initial classification model should be extended to incorporate a number of additional elements. This revised framework is shown in Figure 2. The grey boxes indicate items which, to date, have been largely ignored in the literature, but which we consider important for future research in this area. Overall, the model can be seen as a blueprint for future research on teams.

\section{Conclusion}

There are long-standing theoretical arguments to support the belief that the adoption of formal team structures and the use of employee participation programmes can provide many benefits for organizations. More recently, a number of researchers have attempted to measure the link to performance directly and comprehensively, sometimes using complex econometric models. Our review of a sample of these studies shows that the balance of the evidence supports the proposition that teamwork improves organizational performance.

However, we should take into account the limits of survey research. Even though additional control measures are often included in the models, there will always be omitted variables, and quantitative studies will never explain all the variation we observe. In view of this reductionism, the question arises of whether a survey design is the most appropriate method to test such extended models. This is especially so because measures at the organizational, team and individual level are all required in order to grasp the performance problem fully. Following Ichniowski et al. (1996, 330), we recommend that any quantitative analysis should be complemented by detailed case studies that can observe hard-toquantify data and shed light on crucial details of how the implementation of teamwork leads to success. It is, in other words, important to get inside the black box and to establish how and why people behave and perform as they do.

\section{Note}

1 Corresponding author. E-mail: anne.delarue@ soc.kuleuven.be

\section{References}

Ancona, D.G., Goodman, P.S., Lawrence, B.S. and Tushman, M.L. (2001). Time: a new research lens. Academy of Management Review, 26, 645-663.

Appelbaum, E., Bailey, T., Berg, P. and Kalleberg, A.L. (2000). Manufacturing Advantage. Why HighPerformance Work Systems Pay Off. New York: Cornell University Press.

Auster, R.D. (1979). Shirking in the theory of the firm. Southern Economic Journal, 45, 867-874.

*Bacon, N. and Blyton, P. (2000). High road and low road teamworking: perceptions of management rationales and organizational and human resource outcomes. Human Relations, 53, 1425-1458.

*Banker, R.D., Field, J.M., Schroeder, R.G. and Sinha, K.K. (1996). Impact of work teams on manufacturing performance: a longitudinal field study. Academy of Management Journal, 39, 867-890.

Barker, J.R. (1993). Tightening the iron cage: concertive control in self-managing teams. Administrative Science Quarterly, 38, 408-437.

*Batt, R. (1999). Work organization, technology, and performance in customer service and sales. Industrial and Labour Relations Review, 52, 539-564.

*Batt, R. (2001). The economics of teams among technicians. British Journal of Industrial Relations, 39, 1-24.

*Batt, R. (2004). Who benefits from teams? Comparing workers, supervisors, and managers. Industrial Relations, 43, 183-212. 


\section{Teamworking and organizational performance}

*Batt, R. and Appelbaum, E. (1995). Worker participation in diverse settings: does the form affect the outcome and if so, who benefits? British Journal of Industrial relations, 33, 353-378.

Becker, B.E., Huselid, M.A., Pickus, P.S. and Spratt, M.F. (1997). HR as a source of shareholder value: research and recommendations. Human Resource Management, 36(1), 39-47.

*Benders, J., Huijgen, F., Pekruhl, U. and O'Kelly, K.P. (1999). Useful but Unused Group Work in Europe. Findings from the EPOC Survey. Dublin: European Foundation for the Improvement of Living and Working Conditions.

Benders, J. and Van Hootegem, G. (1999). Teams and their context: moving the team discussion beyond existing dichotomies. Journal of Management Studies, 26, 609-628.

*Black, S.E. and Lynch, L.M. (2001). How to compete: the impact of workplace practices and information technology on productivity. Review of Economics and Statistics, 83, 434-445.

*Boning, B., Ichniowski, C. and Shaw, K. (2001). Opportunity Counts: Teams and the Effectiveness of Production Incentives. NBER Working Paper No. 8306. Cambridge, MA: National Bureau of Economic Research.

Campion, M., Medsker, G. and Higgs, A. (1993). Relations between work group characteristics and effectiveness: implications for designing effective work groups. Personnel Psychology, 46, 823-850.

*Cappelli, P. and Neumark, D. (2001). Do 'highperformance' work practices improve establishmentlevel outcomes? Industrial and Labour Relations Review, 54, 737-775.

Cohen, S.G. and Bailey, D.E. (1997). What makes teams work: group effectiveness research from the shop floor to the executive suite. Journal of Management, 23, 239-290.

Cohen, S.G. and Ledford, G.E. (1994). The effectiveness of self-managing teams: a quasi-experiment. Human Relations, 47, 13-43.

*Cohen, S.G., Ledford, G.E. and Spreitzer, G.M. (1996). A predictive model of self-managing work team effectiveness. Human Relations, 49, 643-676.

*Cooke, W.N. (1994). Employee participation programs, group-based incentives, and company performance: a union-nonunion comparison. Industrial and Labour Relations Review, 47, 594-609.

Covin, J., Slevin, D. and Schultz, R. (1994). Implementing strategic missions: effective strategic, structural and tactical choices. Journal of Management Studies, 31, 481-505.
*Delarue, A., Van Hootegem, G., Huys, R. and Gryp, S. (2004). Dossier: Werkt teamwerk? De PASOresultaten rond arbeidsorganisatie doorgelicht. Leuven: Hoger Instituut voor de Arbeid, Departement TEW, Departement Sociologie (KU Leuven).

De Sitter, L.U. (1994). Synergetisch produceren. Human resources mobilisation in de productie: een inleiding in de structuurbouw. Assen: Van Gorcum.

De Sitter, L.U., Den Hertog, J.F. and Dankbaar, B. (1997). From complex organizations with simple jobs to simple organizations with complex jobs. Human Relations, 50, 497-534.

*DeVaro, J. (2006). Teams, autonomy, and the financial performance of firms. Industrial Relations, 45, 217-269.

De Winne, S. and Sels, L. (2003). HRM and performance, research without theory? A literature review. Research Report, Department of Applied Economics, 0333, 44.

Doorewaard, H., Huys, R. and Van Hootegem, G. (2002). Team responsibility structure and team performance. Personnel Review, 31, 356-370.

*Dunlop, J.T. and Weil, D. (1996). Diffusion and performance of modular production in the U.S. apparel industry. Industrial Relations, 35, 334-355.

Dunphy, D. and Bryant, B. (1996). Teams: panaceas or prescriptions for improved performance? Human Relations, 49, 677-699.

Dyer, L. and Reeves, T. (1995). Human resource strategies and firm performance: what do we know and where do we need to go? International Journal of Human Resource Management, 6, 656670.

*Elmuti, D. (1997). The perceived impact of teambased management systems on organizational effectiveness. Team Performance Management, 3(3), 179-192.

Gladstein, D. (1984). Groups in context: a model of task group effectiveness. Administrative Science Quarterly, 29, 499-517.

*Glassop, L.I. (2002). The organizational benefits of teams. Human Relations, 55, 225-249.

Glew, D.J., O'Leary-Kelly, A.M., Griffin, R.W. and Van Fleet, D.D. (1995). Participation in organizations: a preview of the issues and proposed framework for future analysis. Journal of Management, 21, $395-421$.

*Godard, J. (2001). High performance and the transformation of work? The implications of alternative work practices for the experience and outcomes of work. Industrial and Labour Relations Review, 54, 776-805. 
Guest, D.E. (2001). Human resource management: when research confronts theory. International Journal of Human Resource Management, 12, 1092-1106.

Guest, D.E., Michie, J., Conway, N. and Sheehan, M. (2003). Human resource management and corporate performance in the UK. British Journal of Industrial Relations, 41, 291-314.

Guzzo, R.A. and Dickson, M.W. (1996). Teams in organizations: recent research on performance and effectiveness. Annual Review of Psychology, 47, 307-338.

Hackman, J.R. (1987). The design of work teams. In Lorsch, J.W. (ed.), Handbook of Organizational Behaviour. Englewood Cliffs, NJ: Prentice Hall.

Hackman, J.R. and Oldham, G.R. (1976). Motivation through the design of work: test of a theory. Organizational Behaviour and Human Performance, 16, 250-279.

Hackman, J.R. and Oldham, G.R. (1980). Work Redesign. Reading, MA: Addison-Wesley.

*Harley, B. (2001). Team membership and the experience of work in Britain: an analysis of the WERS98 data. Work, Employment and Society, 15, 721-742.

Hammer, M. and Champy, J. (1993). Reengineering the Corporation: A Manifesto for Business Revolution. New York: HarperCollins.

*Hamilton, B.H., Nickerson, J.A. and Owan, H. (2003). Team incentives and worker heterogeneity: an empirical analysis of the impact of teams on productivity and participation. Journal of Political Economy, 111, 465-497.

Hart, S. and Banbury, C. (1994). How strategymaking processes can make a difference. Strategic Management Journal, 15, 251-269.

Ichniowski, C., Kochan, T.A., Levine, D., Olson, C. and Strauss, G. (1996). What works at work: overview and assessment. Industrial Relations, 35, 299-333.

*Ichniowski, C., Shaw, K. and Prennushi, G. (1997). The effects of human resource management practices on productivity: a study of steel finishing lines. American Economic Review, 87, 293-313.

Karau, S.J. and William, K.D. (1993). Social loafing: a meta-analytic review and theoretical integration. Journal of Personality and Social Psychology, 65, 681-706.

Katzenbach, J. and Smith, D. (1993). The Wisdom of Teams: Creating the High Performance Organization. Cambridge, MA: Harvard Business School Press.
Kleinschmidt, M. and Pekruhl, U. (1994). Kooperation, Partizipation und Autonomie: Gruppenarbeit in deutschen Betrieben. Arbeit, 4, 150-172.

Kuipers, H. and Van Amelsvoort, P. (1990). Slagvaardig organiseren, inleiding in de sociotechniek als integrale ontwerpleer. Deventer: Kluwer.

Lawler, E.E. (1992). The Ultimate Advantage: Creating the High Involvement Organization. San Francisco, CA: Jossey-Bass.

Leamer, E.E. (1983). Let's take the con out of econometrics. American Economic Review, 73, 31-43.

Manz, C. and Sims, H. (1980). Self management as a substitute for leadership: a social learning theory perspective. Academy of Management Review, 5, 361-367.

Manz, C.C. and Sims, H.P. (1987). Leading workers to lead themselves: the external leadership of selfmanaging work teams. Administrative Science Quarterly, 32, 106-128.

*Mathieu, J.E., Gilson, L.L. and Ruddy, T.M. (2006). Empowerment and team effectiveness: an empirical test of an integrated model. Journal of Applied Psychology, 91, 97-108.

*McNabb, R. and Whitfield, K. (1997). Unions, flexibility, team working and financial performance. Organization Studies, 18, 821-838.

Mueller, F., Procter, S. and Buchanan, D. (2000). Teamworking in its context(s): antecedents, nature and dimensions. Human Relations, 53, 13871424.

Osterman, P. (1994). How common is workplace transformation and who adopts it? Industrial and Labour Relations Review, 47, 173-188.

* Osterman, P. (2000). Work reorganization in an era of restructuring: trends in diffusion and effects on employee welfare. Industrial and Labour Relations Review, 53, 179-196.

Pasmore, W.A. (1988). Designing Effective Organizations: the Sociotechnical Systems Perspective. New York: Wiley.

*Paul, A.K. and Anantharaman, R.N. (2003). Impact of people management practices on organizational performance: analysis of a causal model. International Journal of Human Resource Management, 14, 1246-1266.

*Power, J. and Waddell, D. (2004). The link between self-managed work teams and learning organisations using performance indicators. The Learning Organization, 11, 244-259.

*Procter, S. and Burridge, M. (2004). Extent, intensity and context: teamworking and performance in the 1998 UK Workplace Employee Relations 


\section{Teamworking and organizational performance}

Survey (WERS 98). IIRA HRM Study Group Working Papers in Human Resource Management, No. 12.

Ramsay, H., Scholarios, D. and Harley, B. (2000). Employees and high-performance work systems: testing inside the black box. British Journal of Industrial Relations, 38, 501-531.

Robbins, H. and Finley, M. (1995). Why Teams Don't Work. Princeton, NJ: Peterson's/Pacesetter Books.

Rust, R.T., Lehmann, D.R. and Farley, J.U. (1990). Estimating publication bias in meta-analysis. Journal of Marketing Research, 27, 220-227.

Salas, E., Burke, C.S. and Cannon-Bowers, J.A. (2000). Teamwork: emerging principles. International Journal of Management Reviews, 2, 339-356.

Schumann, M., Baethge-Kinsky, V., Kuhlmann, M., Kurz, C. and Neumann, U. (1994). Trendreport Rationalisierung - Automobilindustrie, Werkzeugmaschinenbau, Chemische Industrie. Berlin: Edition Sigma.

Sels, L. (2002). Strategisch Management van Human Resources. Maakt het een verschil? Inaugurale les Belgische Francqui-leerstoel 2002-2003. Universiteit Antwerpen, Faculteit Toegepaste Economische Wetenschappen.

Shepperd, J.A. (1993). Productivity loss in performance groups: a motivation analysis. Psychological Bulletin, 113, 67-81.

Sims, H. and Manz, C. (1996). Company of Heroes: Unleashing the Power of Self-leadership. New York: Wiley.

Sinclair, A. (1992). The tyranny of a team ideology. Organization Studies, 13, 611-626.

Starbuck, W. and Mezias, J. (1996). Opening Pandora's box: studying the accuracy of managers' perceptions. Journal of Organizational Behaviour, 17, 99-117.

*Stewart, G.L. and Barrick, M.R. (2000). Team structure and performance: assessing the mediating role of intrateam process and the moderating role of task type. Academy of Management Journal, 43, $135-148$.
*Tata, J. and Prasad, S. (2004). Team self-management, organizational structure, and judgements of team effectiveness. Journal of Managerial Issues, 16, 248-265.

Van Hootegem, G. (2000). De draaglijke traagheid van het management. Leuven: Acco.

Wall, T. and Martin, R. (1987). Job and work design. In Cooper, C. and Robertson, I. (eds), International Review of Industrial and Organisational Psychology. Chichester: Wiley.

Waterson, P., Clegg, C., Bolden, R., Pepper, K., Warr, P. and Wall, T. (1997). The Use and Effectiveness of Modern Manufacturing Practices in the United Kingdom. Sheffield: Institute of Work Psychology.

*West, M.A., Borrill, C., Dawson, J., Scully, J., Carter, M., Anelay, S., Patterson, M. and Waring, J. (2002). The link between the management of employees and patient mortality in acute hospitals. International Journal of Human Resource Management, 13, 1299-1310.

Womack, J.P., Jones, D.T. and Roos, D. (1991). The Machine that Changed the World. The Story of Lean Production. How Japan's Secret Weapon in the Global Auto Wars Will Revolutionize Western Industry. New York: Harper Perennial.

*Zwick, T. (2004). Employee participation and productivity. Labour Economics, 11, 715-740.

Anne Delarue and Geert Van Hootegem are from the Catholic University of Louvain, Centre for Sociological Research, Section Work and Organisation, E. Van Evenstraat 2B, 3000 Leuven, Belgium. Stephen Procter is from the University of Newcastle, Business School, Armstrong Building, Newcastle Upon Tyne NE1 7RU, UK. Mark Burridge is from the School of Management, University of Leicester, Leicester LE1 7RH, UK. 